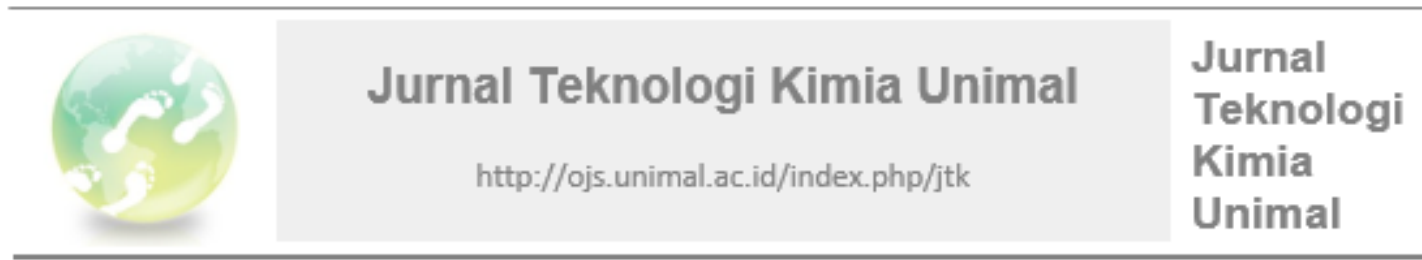

\title{
OPTIMASI PEMBUATAN BRIKET BERBASIS LIMBAH AMPAS TEBU MENGGUNAKAN METODE RSM (Response Surface methodology)
}

\author{
Leni Maulinda1), Hadizah Mardinata'), Jalaluddin ${ }^{3)}$ \\ Jurusan Teknik Kimia, Fakultas Teknik Universitas Malikussaleh, \\ 24352, Aceh Utara, Indonesia. \\ Email: hadizah mardinata@yahoo.com
}

\begin{abstract}
ABSTRAK
Dalam penelitian ini limbah ampas tebu dimanfaatkan sebagai bahan bakar dengan cara mengubahnya menjadi briket bioarang. Bioarang yang sebenarnya termasuk bahan lunak yang dengan proses tertentu diolah menjadi bahan arang keras. Kualitas dari bioarang ini tidak kalah dengan batubara atau bahan bakar jenis arang lainnya. Briket berguna sebagai bahan bakar alternatif dalam industri. Manfaat yang diharapkan dari penelitian ini adalah dapat memberikan informasi bahwa arang ampas tebu dapat digunakan sebagai alternatif bahan bakar, sehingga dapat diaplikasikan untuk mengurangi bahan bakar fosil. Adapun tujuan penelitian ini untuk mengkaji kondisi operasi pada suhu dan waktu pembakaran diproses karbonisasi, menganalisa kadar air, kadar abu dan nilai kalor menggunakan metode RSM (Response Surface Methodology). Berdasarkan hasil penelitian diperoleh Briket ampas tebu dengan kadar air terendah 0,23\%, kadar abu terendah $0,23 \%$, dan nilai kalor terbaik adalah $1.906 \mathrm{~J} / \mathrm{g}$. Dari hasil metode Response Surface Methodology di dapatkan hasil optimasi Briket terbaik yaitu $314,64^{\circ} \mathrm{C}$ dan berat arang 11,12 gram dengan kadar air $0,61 \%$, kadar abu $0,34 \%$
\end{abstract}

Kata Kunci: Briket, Ampas tebu, kadar Air, Kadar Abu dan Nilai Kalor.

\begin{abstract}
In this research sugarcane bagasse waste is used as fuel by turning it into bioarang briquettes. Bioarang actually includes soft materials which in certain processes are processed into hard charcoal. The quality of this bioarang is not inferior to coal or other types of charcoal fuel. Briquette is useful as an alternative fuel in the industry. The expected benefit of this research is that it can provide information that sugarcane bagasse can be used as an alternative fuel, so that it can be applied to reduce fossil fuels. The purpose of this study is to examine the operating conditions at the temperature and time of combustion processed carbonization, analyze water content, ash content and heating value using the RSM (Response Surface Methodology) method. Based on the research results obtained bagasse Briquette with the lowest water content $0.23 \%$, the lowest ash content $0.23 \%$, and the best heating value is $1,906 \mathrm{~J} / \mathrm{g}$. From the results of the Response Surface Methodology method the best briquette optimization results are $314.640 \mathrm{C}$ and 11.12 grams of charcoal weight with a moisture content of $0.61 \%$, ash content of $0.34 \%$.
\end{abstract}

Keywords: Briquettes, Sugarcane pulp, Moisture Content, Ash Content and Calorific Value.

\section{PENDAHULUAN}

Konsumsi bahan bakar di Indonesia sejak tahun 1995 telah melebihi produksi dalam negeri. Diperkirakan dalam kurun waktu 10-15 tahun kedepan cadangan minyak di Indonesia akan menipis. Perkiraan ini terbukti dengan seringnya terjadi kelangkaan BBM di beberapa daerah di Indonesia (Hambali, 2006).
Kelangkaan dan kenaikan harga minyak akan terus menerus terjadi karena sifatnya yang non-renewable. Hal ini harus segera diimbangi dengan penyediaan sumber anergi alternatif yang renewable, melimpah jumlahnya dan murah harganya, sehingga terjangkau oleh masyarakat.

Limbah ampas tebu mempunyai peluang untuk dimanfaatkan secara optimal sebagai energi alternatif yang bermanfaat bagi 


\section{Jurnal Teknologi Kimia Unimal}

http://ojs.unimal.ac.id/index.php/jtk
Jurnal

Teknologi

Kimia

Unimal kebutuhan masyarakat dan ramah terhadap lingkungan. Pemanfaatan dilakukan dengan cara mengubah limbah ampas tebu menjadi briket. Briket yang dibuat adalah briket bioarang dengan diarangkan terlebih dahulu limbah ampas tebu kemudian diayak dan dicampur dengan bahan perekat.

Biomassa merupakan bahan yang dapat diperoleh dari tanaman baik secara langsung maupun tidak langsung dan dimanfaatkan sebagai energi atau bahan dalam jumlah yang besar. Biomassa disebut juga sebagai "Fitomassa" dan sering diterjamahkan sebagai bioresuorce atau sumber daya yang diperoleh dari hayati. Biomassa sebenarnya dapat digunakan secara langsung tanpa melalui pembuatan arang terlebih dahulu (Yokoyama, 2008).

Biomassa sebenarnya dapat digunakan langsung tanpa memlalui proses pembuatan arangnya terlebih dulu. Namun manfaat biomassa nya secara langsung akan kurang efesien. Salah satu contohnya yaitu pada penggunaan kayu sebagai bahan bakar, energi yang terpakai kurang dari $10 \%$.

Selain itu, pembuatan arang dapat meningkatkan energi yang dihasilkan. Energi yang dihasilkan dari pembakaran kayu hanya $2.300 \mathrm{kkal} / \mathrm{g}$, sedangkan energi yang dihasilkan dari pembakaran bioarang bisa mencapai $5.000 \mathrm{kkal} / \mathrm{g}$ (Setiawan, 2007)

Namun, pemanfaatan biomassa secara langsung ini kurang efisien. Sebagai contoh, pada penggunaan kayu sebagai bahan bakar, energi yang terpakai kurang dari $10 \%$. Selain itu, pembuatan bioarang dapat meningkatkan energi yang dihasilkan. Sebagai gambaran, energi yang dihasilkan dari pembakaran kayu hanya $3.300 \mathrm{kkal} / \mathrm{g}$, sedangkan energi yang dihasilkan dari pembakaran bioarang dapat mencapai $5.000 \mathrm{kkal} / \mathrm{g}$ (Setiawan, 2007).

Bioarang adalah arang (salah satu jenis bajan bakar) yang dibuat dari aneka macam bahan nabati atau biomassa, misalnya kayu, ranting, daun-daunan, rumput jerami, dan limbah pertanian lainnya.

Bioarang ini dapat digunakan sebagai bahan bakar yang tidak kalah dari bahan bakar jenis lainnya. Akan tetapi, untuk pemaksimal pemanfaatan nya bioarang ini masih harus melalui sedikit proses pengolahan sehingga menjadi briket yang sesungguhnya (dani Sucipto, 2012).

Briket Bioarang adalah gumpalangumpalan atau batang-batangan arang yang terbuat dari bioarang (bahn lunak). Kualitas bioarang juga tidak kalah dengan kualitas batibara atau bahan bakar jenis arang lainnya.

Ampas tebu adalah hasil limbah dari industri gula atau pembuatan minuman dari air tebu yang belum termanfaatkan secara optimal sehingga mambawa masalah tersendiri bagi industri gula maupun lingkungan karena dianggap sebagai limbah.

Secara kimiawi, komponen utama penyusun ampas tebu adalah serat yang di dalamnya terkandung gugus selulosa, poliosa, hemiselulosa, lignoselulosa dan lignin (sentosa, 2003).

Pada penelitian ini penulis menggunakan bahan baku ampas tebu sebagai biomassa yang kemudian dicampurkan dengan tepung kanji sebagai perekat dan menggunakan metode RSM (Response Surface Methodology) untuk pembuatan briket bioarang.

Pemilihan ini dilakukan karena ampas tebu di Aceh ditemukan dalam jumlah yang cukup banyak dan belum di manfaatkan secara optimal. Analisa proksimat dan analisa nilai kalor dilakukan pada briket yang dihasilkan untuk mengetahui potensi pemanfaatan briket ini sebagai bahan bakar alternatif.

\section{METODOLOGI}

\subsection{Bahan dan Alat}

Bahan yang digunakan adalah Ampas tebu yang sebelumnya di karbonasi dengan suhu yang di variasikan. Bahan selanjutnya adalah kanji dan sedikit air.

Alat utama yang digunakan adalah seperangkat alat untuk pembakaran, seperangkat alat untuk menghaluskan, loyang, neraca analitik, mesh, oven, disikator dan kalori meter untuk pengujian nilai kalor pada briketnya.

\subsection{Prosedur Kerja}




\section{Jurnal Teknologi Kimia Unimal}

http://ojs.unimal.ac.id/index.php/jtk

Jurnal

Teknologi

Kimia

Unimal
Adapun prosedur kerja pada penelitian ini adalah:

1. Ampas tebu sebelumnya di bersihkan dan dipotong kecil-kecil kemudian di keringkan menggunakan oven $105^{\circ} \mathrm{C}$.

2. Kemudian dikarbonasi menggunakan furnace dengan suhu yang telah di variasikan kemudian di ayak dengan 20 mesh.

3. Ampas tebu yang telah di ayak dan dihaluskan kemudian dicampur dengan larutan kanji yang sudah dikentalkan terlebih dahulu.

4. Adonan dicetak dengan cetakan briket .

5. Kemudian di oven dengan suhu $105^{\circ} \mathrm{C}$ selama 5 jam.

6. Ulangi prosedur diatas dengan takaran berat arang dan kanji yang telah di variasikan.

7. Adonan yang sudah kering kemudian di dinginkan dan di Analisa.

\subsection{Tahap Analisa}

\subsubsection{Analisa Kadar Air}

Kadar air dapat ditentukan dengan cara menghitung kehilangan berat dari contoh yang dipanaskan pada kondisi standar. Hitung kadar air dengan menggunakan rumus:

$$
\text { Kadar Air }=\frac{(\text { berat awal }- \text { berat akhir) }}{\text { berat awal }} \times 100 \%
$$

\subsubsection{Analisa Kadar Abu}

Kadar abu ditentukan dengan cara menimbang residu (sisa) pembakaran sempurna dari contoh pada kondisi standar. Hitung kadar abu dengan rumus:

$$
\text { Kadar Abu }=\frac{(\text { berat awal }- \text { berat akhir })}{\text { berat awal }} \times 100 \%
$$

\subsubsection{Uji Nilai Kalor}

Bomb calorimeter adalah alat yang digunakan untuk mengukur jumlah kalor (nilai kalori) yang dibebaskan pada pembakaran sempurna (dalam $\mathrm{O}_{2}$ berlebih) suatu senyawa, bahan makanan, bahan bakar.

Sejumlah sampel ditempatkan pada tabung beroksigen yang tercelup dalam medium penyerap kalor (kalorimeter), dan sampel akan terbakar oleh api listrik dari kawat logam terpasang dalam tabung.

\section{HASIL DAN PEMBAHASAN}

3.1 Hasil

Adapun hasil yang didapatkan setelah melakukan penelitian yaitu dapat dilihat pada tabel 3.1 di bawah ini.

Tabel 3.1 Data Hasil Penelitian

\begin{tabular}{|c|c|c|c|c|}
\hline \multirow{2}{*}{ std } & \multicolumn{2}{|c|}{ Variabel Bebas } & \multicolumn{2}{|c|}{$\begin{array}{c}\text { Variabel } \\
\text { Terikat }\end{array}$} \\
\hline & $\begin{array}{c}\text { Suhu } \\
\text { Karbonasi } \\
\left({ }^{\circ} \mathrm{C}\right)\end{array}$ & $\begin{array}{c}\text { Berat } \\
\text { Arang } \\
(\mathrm{g})\end{array}$ & $\begin{array}{c}\text { Kadar } \\
\text { Air } \\
(\%) \\
\end{array}$ & $\begin{array}{c}\text { Kadar } \\
\text { Abu } \\
(\%) \\
\end{array}$ \\
\hline 1 & 314,64 & 6,88 & 0,67 & 0,49 \\
\hline 2 & 314,64 & 11,12 & 0,45 & 0,74 \\
\hline 3 & 385,36 & 6,88 & 1,72 & 0,28 \\
\hline 4 & 385,36 & 11,12 & 1,37 & 0,32 \\
\hline 5 & 350 & 6,00 & 0,66 & 0,49 \\
\hline 6 & 350 & 12,00 & 0,99 & 0,33 \\
\hline 7 & 300 & 9,00 & 0,23 & 0,74 \\
\hline 8 & 400 & 9,00 & 2,40 & 0,23 \\
\hline 9 & 350 & 9,00 & 0,88 & 0,37 \\
\hline 10 & 350 & 9,00 & 0,88 & 0,37 \\
\hline 11 & 350 & 9,00 & 0,88 & 0,37 \\
\hline 12 & 350 & 9,00 & 0,88 & 0,37 \\
\hline 13 & 350 & 9,00 & 0,88 & 0,37 \\
\hline
\end{tabular}
Menggunakan Softwere Design Expert V.7.0.0

\subsection{Pembahasan}

Berdasarkan hasil penelitian maka dapat dibahas pengaruh suhu karbonasi dan berat arang terhadap kadar air, kadar abu, nilai kalor pada briket.

\subsubsection{Pengaruh Suhu Karbonasi dan berat arang Terhadap Kadar Air pada Briket Ampas Tebu}




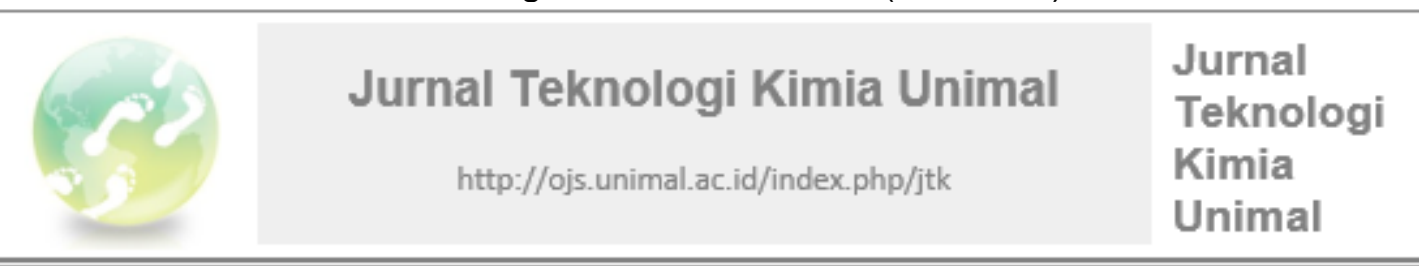

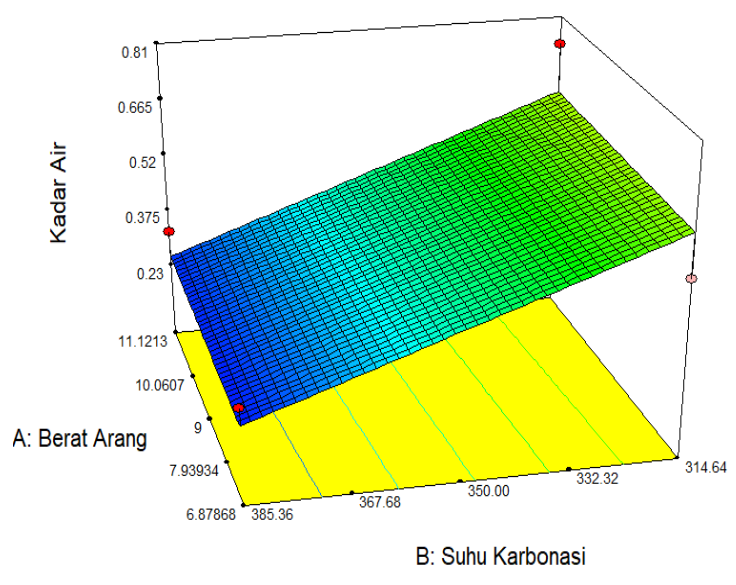

Gambar 3.1 Pengaruh Suhu Karboasi dan Berat Arang terhadap Kadar Air

Gambar 3.1 menunjukkan nilai kadar air yang di hasilkan dari penelitian berkisar antara $0,2-0,8 \%$, Kadar ini telah memenuhi persyaratan pembuatan briket menurut SNI 06-3730-1995 yaitu kurang dari 15\%, Temperatur dan lamanya karbonasi memberikan pengaruh yang signifikan terhadap kadar air yang bisa diserap. Pada penelitian ini semuan sampel briket telah memenuhi standar kadar air, Kadar air tertinggi dimiliki oleh sampel briket yang dikarbonasi pada suhu $300^{\circ} \mathrm{C}$ dengan berat arang 9 gram dan kadar air terendah pada sampel briket yang di karbonasi pada suhu $400{ }^{\circ} \mathrm{C}$ dengan berat arang 9 gram.

Hal serupa juga diungkapkan oleh Sjostrom dalam Nailul Fauziah (2011) yang menyatakan bahwa semakin tinggi suhu maka semakin meningkat proses dehidrasi dalam briket sehingga air yang terkandung semakin banyak yang menguap dan kadar air nya akan semakin rendah. Kadar air yang sedikit akan meningkatkan kemampuan briket karena meningkatkan daya serap terhadap cairan, dengan semakin kecil molekul air dalam briket maka halangan molekul lain untuk masuk akan semakin kecil (Pari, 1996).

\subsubsection{Pengaruh Suhu Karbonasi dan Berat Arang Terhadap Kadar Abu Pada Briket Ampas Tebu}

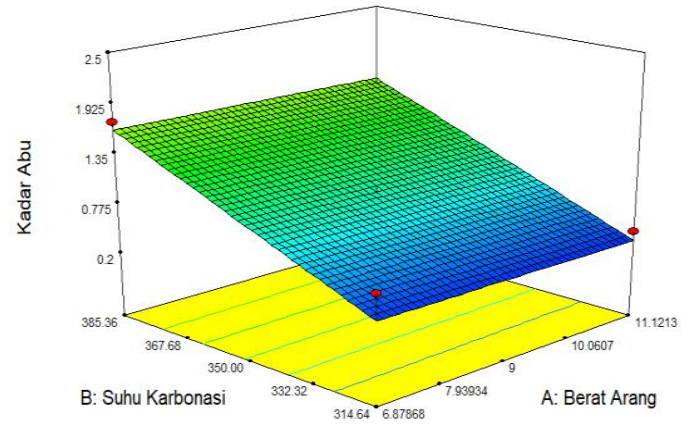

Gambar 3.2 Pengaruh Suhu dan Berat Terhadap Kadar Abu Pada Briket

Gambar 3.2 dapat diketahui semakin tinggi suhu karbonasi maka kadar abu semakin meningkat. Peningkatan ini disebabkan oleh kenaikan suhu karbonasi yang memicu teroksidasinya sebagian besar zat volatile termasuk briket. Sedangkan abu bukan merupakan zat volatile sehingga tidak terikut teroksidasi. Kadar abu terendah didapatkan pada suhu $300^{\circ} \mathrm{C}$ dengan berat arang 9 gram sebesar $0,23 \%$. dan kadar akarbon tertinggi pada suhu $400{ }^{\circ} \mathrm{C}$ dengan berat arang 9 gam sebesar 2,40\% kadar ini memenuhi persyaratan briket menurut (SNI) 06-3730-1995 mak. 10\%.

Pada suhu $300{ }^{\circ} \mathrm{C}$ briket yang dihasilkan masih memiliki sisa-sisa bahan organik yang belum sempat menguap yang kadarnya lebih banyak dibandingkan kadar abunya. Semakin tinggi suhu maka kadar abu semakin meningkat.

Menurut Sudrajat dalam Nailul Fauziah (2009), peningkatan kadar abu dapat terjadi akibat terbentuknya garam-garam mineral pada saat proses pengarangan yang bila dilanjutkan akan membentuk partikel-partikel halus dari garam mineral yang akan menyumbat pori pada briket tersebut.

\subsubsection{Nilai Kalor (Heating Value/Calorific Value) \\ Pengujian nilai kalor dilakukan dengan} menggunakan alat Bomb. Pengujian ini dilakukan untuk melihat nilai kalor yang terkandung dalam setiap sampel yang diamati dari besar kenaikan temperatur air setelah 


\section{Jurnal Teknologi Kimia Unimal}

http://ojs.unimal.ac.id/index.php/jtk

Jurnal

Teknologi

Kimia

Unimal

sampel mengalami pembakaran sempurna dalam Bomb Kalorimeter. Adapun hasil yang pengujian nilai dapat dilihat pada Tabel 3.2.

Tabel 3.2 hasil analisa nilai kalor

\begin{tabular}{|l|l|l|l|}
\hline No & $\begin{array}{l}\text { Nama } \\
\text { Sampel }\end{array}$ & Spesifikasi & $\begin{array}{l}\text { Nilai Kalor } \\
(\mathrm{J} / \mathrm{g})\end{array}$ \\
\hline 1 & Briket & Run 1 & 3.906 \\
\hline 2 & Briket & Run 2 & 3.944 \\
\hline
\end{tabular}

Dari tabel 3.2 terlihat nilai kalor yang dihasilkan oleh briket yang terbuat oleh ampas tebu memiliki nilai kalor yang memenuhi standar kualitas briket arang SNI (SNI 016235-2000) dan juga standar kualitas briket dari beberapa negara. Pada Run 1 nilai kalor yang dimiliki adalah $3.906 \mathrm{~J} / \mathrm{g}$ dan pada Run 2 adalah $3.944 \mathrm{~J} / \mathrm{g}$. Sehingga Run 2 nilai kalornya lebih tinggi dibandingkan dengan Run 1.

Dapat di simpulkan bahwa hasil metode Response Surface Methodology di dapatkan hasil optimasi briket dari ampas tebu yang terbaik yaitu pada berat arang 11,12 gram pada suhu karbonasi $314,64^{\circ} \mathrm{C}$ dengan kadar air $0,45 \%$, kadar abu $0,74 \%$ dan nilai kalor $1.944 \mathrm{~J} / \mathrm{g}$.

\section{KESIMPULAN}

Berdasarkan hasil penelitian dan pembahasan, maka dapat diambil kesimpulan sebagai berikut:

1. Pembuatan briket dari ampas tebu harus melakukan nilai uji kalor untuk menentukan briket tersebut bisa digunakan atau. Semakin besar nilai kalor yang dimiki maka semakin besar pula briket layak digunakan.

2. Pada hasil penelitian diperoleh briket ampas tebu yang memiliki kadar air dan akar abu terendah yaitu pada run 7 dan run 8 dengan kadar air 0,23\% dan kadar abu $0,23 \%$.

3. Pada hasil RSM di dapatkan hasil optimasi briket dari ampas tebu yang terbaik yaitu pada berat arang 11,12 gram pada suhu karbonasi $314,64^{\circ} \mathrm{C}$ dengan kadar air 0,45 $\%$, kadar abu 0,74 \% dan nilai kalor 3.944 $\mathrm{J} / \mathrm{g}$.

\section{DAFTAR PUSTAKA}

Atkins, P.W. 1999. Kimia Fisika 2. Jakarta : Erlangga.

Birowo, A.T. 1992. Seri Manajemen Usaha Perkebunan Gula, Edisi Pertama. Jogyakarta : LPP.

Dani Sucipto, SKM., M.Sc., "Teknologi Pengolahan Daur Ulang Sampah", Gosyen Publishing, Yogyakarta 2012

Gadd, G.M. 1998. Biotechnology vol 6. pp: 401-433

Hanjono, L. 1995. Teknologi Kimia. Jakarta : PT Pradnya Paramita.

Hambali, E., "Jarak Pagar Tanaman Penghasil Biodiesel', Penebar Swadaya, Bogor 2006

Kurniawan, "Superkarbon, Bahan Bakar Alternatif Pengganti Minyak Tanah dan Gas", Penebar Swadaya, Cimanggis, Depok 2008.

Lina Suhendarwati, et al. 2010. Pengaruh Konsentrasi Larutan Kalium Hidroksida pada Abu Dasar Ampas Tebu Teraktivasi. Malang : Universitas Brawijaya. Jurnal Sumberdaua Alam \& Lingkungan

Marni Wiryanti dan Jumnaini Fatmawati. 2002. Pengaruh Ukuran Partikel dan Pengikat pada Pembuatan Briket dari Ampas Tebu. Indralaya: Jurusan Teknik Kimia UNSRI.

Maulana, Rudi. 2008. Pembuatan Briket Batu bara. Palembang: Jurusan Teknik Kimia POLTEK

Nursyiwan dan Nuryetti. 2005. Pembuatan Briket Arang dari Serbuk Gergaji. Jakarta: LIPI.

Ria Faulina, et al. .2011. Response Surface Methodology (RSM) dan Aplikasinya. 


\section{Jurnal Teknologi Kimia Unimal}

http://ojs.unimal.ac.id/index.php/jtk

Jurnal

Teknologi

Kimia

Unimal
Surabaya: Institusi Teknologi Sepuluh Nopember.

Riki irwandi, et al. 2015. Penentuan Massa dan Waktu Kontak Optimum Adsorpsi Karbon Aktif dari Ampas Tebu Sebagai Adsorben Logam Berat Pb. Pekan baru: Universitas Riau. Jurnal JOM FTEKNIK Volume 2 No 2.

Rati Yuliar Ningsih dan Ria Sofia Anggraeni. 2006. Laporan Kerja Praktek di Perusahaan Briket Unit Tanjung Enim PT. Tambang Batubara Bukit Asam (PERSERO), Tbk. Indralaya: Jurusan Teknik Kimia UNSRI.

Ranada Vinisah, et al, 2014. Pembuatan Karbon Aktif Dari Cangkang Kulit Buah Karet (Hevea brasilliensis). Universitas Sriwijaya

Roni, et al. 2015. Penyerapan Logam Fe dengan Menggunakan Karbon Aktif dari Amaps Terbu yang diaktifasi dengan $\mathrm{KOH}$. Pekanbaru : Universitaas Riau. Jurnal JOM FTEKNIK Volume 2 No 1.

Sudrajat. 1982. Produksi Arang dan Briket Arang serta Prospek Pengusahaannya.

Bogor: Pusat Penelitian dan Pengembangan kehutanan Departemen Pertanian

Setyawati Tobing, Febrina dan Adi Chandra Brades. 2007. Pembuatan Briket Bioarang dari Eceng Gondok (Eichornia crasipesssolm) dengan Sagu sebagai Pengikat. Indralaya: Jurusan Teknik Kimia UNSRI.

Selvi, K., Pattabhi S and Kardivelu K. 2001. Removal of $\mathrm{Cr}(\mathrm{VI})$ from Aqueous Solution by Adsorption Onto Activated Carbon. Bioresour Technol. Vol 80 : 87-89.

Subrata, J. 1993. Daur Ulang Kapur dalam Blontong pada Pabrik Gula. Skripsi Jogyakarta : Kimia FMIPA UGM.
Selfiani, Indri. 2006. Penggunaan Cangkang Kelapa Sawit (Elaeis Guineesis Jack) sebagai Bahan Baku Pembuatan Briket Bioarang dengan Variasi Temperatur. Indralaya: Jurusan Pendidikan Matematika dan IImu Pengetahuan Alam UNSRI.

Sukandarrumidi. 1995. Batubara dan Gambut. Yogyakarta: Gadjah Mada University Press.

Supriyono. 1997. Pembuatan arang Aktif dari Serbuk Gergaji Kayu Jati dengan Bahan Pengaktif Asam Klorida. Yogyakarta: Jurusan Matematika dan IImu Pengetahuan Alam (MIPA) UNY.

Setiawan, "Memanfaatkan Kototran Ternak, Solusi Masalah Lingkungan Dan Pemanfaatan Energi Alternatif', Penebar Swadaya, Cimanggis, Depok 2007.

Santosa, S.J., Jumina dan Sri S. 2003. Sintesis Membran Bio Urai Selulosa Asetat dan Adsorben Super Karboksimetil selulosa dari Selulosa Ampas Tebu Limbah Pabrik Gula. Jogyakarta : FMIPA UGM.

Widowati, Tri. 2003. Pembuatan Arang Aktif dari Serbuk Gergaji Kayu Mahoni dan Uji Kualitas. Yogyakarta: UNY.

Winaya, Suprapta, "Prospek Energi dari Sekam Padi dengan Teknologi Fluidized Bed Combustion", 2008

Yokoyama, S., "Buku panduan biomassa asia", The Japan Institute Of Energy, Japan 2008. 